\title{
ARTICLES
}

\section{The Next Generation of Capital and County Government Offices Developments in Hungarian Middle-Level State Administration Since $2011^{*}$}

\begin{abstract}
Attila Barta**
* Dr. Attila Barta, PhD., senior lecturer at the Department of Administrative Law, Faculty of Law, University of Debrecen. His main fields of research are: middle-level public administration, territorial state administration, organization of public administrative institutions and regulation of local self governments. (e-mail: barta.attila@law.unideb.hu)

** This study has been realized within the framework of the research on the 'New Challenges in the Middle Level State Administration. Trends in the Development of County and Capital Government Offices and District Offices'. The work has been granted by the Hungarian Ministry of Justice.
\end{abstract}

Abstract: The last financial crisis and the rhapsodic developments of Hungarian public administration resulted in a political aspiration that aimed (and still aims) to revitalize the State of Hungary and increase its administrative competitiveness. The territorial representation of the government has been strengthened by the reorganization of the middle level of public administration and the establishment of the new institution of capital and county government offices. The goal of this study is to summarize and evaluate the major steps of the aforesaid process, and to consider the expected further developments in this field.

Keywords: Hungarian public administration; middle-level state administration; territorial representation of Hungarian Government

\section{Introduction}

Public administration systems are complex phenomena, 1 that cannot operate independently of the social, economic, and cultural atmosphere in which they exist. At the same time, no public administration system is absolutely isolated: the European national administrative systems were affected by numerous megatrends in the last 25 years. A continuous need of development was generated by, among others, the globalization, $\underline{2}$ the New Public Management, and the idea of the European Administrative Space. However, while these trends are undoubtedly convergent, they did not result in uniform administrative systems. Public administration systems are still predominantly nation-specific, since they are formed primarily within the framework of national politics. 3

From the onset of the $21^{\text {st }}$ century, but especially since the financial crisis of 2007-09, an increased interest has been observed regarding the classic Weberian bureaucratic traditions in Europe.4 Understandably, this can change the judgement of most elements of public administration systems, including middle-level state administration. Like the energy crisis of the 1970s, the recent crisis induced notable reforms in the public sector, and resulted in the major readjustment of the relationship between the state, the market, the citizens, and the society they live in. 5

At the same time, considering that individual countries faced specific challenges, it cannot be stated that the recent international crises (such as threats of terrorism, environmental disasters, illegal immigration) evoked common crisis management. On the contrary, each country practically reacted to the above challenges in their own specific ways. What is certain, however, is that the re-imagination of the state and administrative roles became of utmost importance. $\underline{6}$

In Hungary, the above process proved to be especially cumbersome, due to the administrative evolution (on-going since the Democratic Transformation) being far from following a clear-cut path: instead, the improvement of Hungarian state administration in the last 25 years is rather a story of burdening reversals and concept changes. Let me point out though, that this tendency generally applies to all countries of the Central- and Eastern European (CEE) region - almost none of them possessed a straightforward concept regarding the roles and responsibilities of the state after Transformation.Z

In my opinion, the above tendencies altogether resulted in a political aspiration, which aimed (and aims) to revitalize the state and increase its competitiveness. Since the executive branch of the state is its administrative apparatus, and the above aspirations required executive actions, the reformation of Hungarian state administration was inevitable.

The goal of this study is to provide detailed data and information on the recent changes of Hungarian middle-level state administration for researchers, and for anyone interested in the topic. The overview first considers the changes 
performed between 2011 and 2014. Then, the executed integration actions of 2015 will be summarized. Finally, the study describes the most recent and upcoming developments in public administration, spearheaded (and to be spearheaded) in 2016 and beyond.

\section{First Steps Toward an Integrated Territorial Public Administration (2011-2014)}

As an organic part of the evolution described above, the legislative branch established the capital and county-based government offices. In administrative sciences, these offices are also known as the territorial, sub-national, or middle-level elements of Hungarian public administration. Thus, I will use these terms interchangeably in this study. $\underline{8}$ The inception and evolution of these 'government offices' (hereafter GOs in short) were performed in line of the following milestones.

Albeit the period of 1990-2010 already had a deconcentrated state administrative organization in Hungary that ensured the territorial representation of the government, middle-level public administration saw the onset of a new era from 1 January 2011.215 deconcentrated organizations have been merged into the so-called capital and county government offices. The rationale behind this transformation was the decrease of territorial division experienced within the administrative system. 10

One of the specialties of the newly-found GOs was the so-called 'distributed structure'. This meant that the offices were divided internally into a Main Office, and to several Specialized Administrative Organs. The Main Office was responsible for the management of joint functions, like IT, procurement, and HR-matters; at the same time, the Specialized Administrative Organs handled specialized administrative duties (as a relic of the roles of the former specialized territorial agencies). The reorganization affected almost 250 institutions in Hungary, which was about half of the entire state administrative organizational circle at that time.

One year after the Fundamental Law of Hungary was enacted, it named the GOs as the general-duty territorial organizations of the government.11 Since then these offices have practised the administrative supervision of the local selfgovernments. 12 To improve their effectiveness of influence over the mid-level processes, the leaders of the GOs (the 'governmental commissioners') also received a key role in coordinating the key investments of the national economy.

The middle-level government offices were vertically expanded in 2013: the 20 GOs received 198 additional deconcentrated offices (the so-called 'district offices', or DOs in short).13 With their introduction, legislation aimed to standardize the rather eclectic image of sub-national state administration functioning between counties and towns. 14

In 2014 the structure of DOs evolved further. The ever-growing network of integrated customer service offices (also known as 'government windows'), operating as part of the DOs, were complemented by several sub-offices and almost a thousand specialized civil servants.

Considering the fact that most of the pre-2015 steps of this reinforcement have already been studied extensively, 15 the rest of my study focuses on the major transformations of 2015, 2016, and beyond.

\section{2015 - Government Offices Reloaded?}

Since 1 April 2015, the model of GOs has been facing yet another transformation. The changes are due to the legislative decision of homogenizing the administrative structure, and merging additional specialized duties into the offices. The course of this transformation is detailed below.

\subsection{Mid-Level Government Offices: Version 2.016}

The political forces intended to continue the path of changes that would increase state (pro)activity, and in which the GOs appear as the integrative connective points of mid-level public administration. However, the ideological framework of these changes has been designated as the Strategy for the Improvement of Public Administration and Public Services, the mid-term improvement documentation of Hungarian public administration, which obviously builds on the existing county- and district-level apparatus, and considers the structure of integrated administrative offices an element worthy of further improvements.17 The strategy aims for a completely reformed user-friendly public administration, to be achieved by 2020 .

Considering that large-scale complicated systems (like the public administration apparatus, and its subsystems) can rarely be reformed within a single political cycle, I find it justified that a long-term strategy has been prepared. 18 At the 
same time, let me point out that while it would be reasonable to align the planning and execution phases to the known EU-level development cycles, the proposed modifications will most probably be scheduled to align the Hungarian election year. Hence, most of the painful changes will be carried out by the government during 2016, or in 2017 the latest.

The reformation of the government offices were executed by an internal and external thread, which are summarized below in more detail.

\subsection{1 'The 3-Is': Increasing Internal Integration}

The laws enacted in 2015 (and the underlying strategy on which they are based) clearly indicate that the main aspiration of the decision makers was to enhance cooperation among the elements of GOs that were rapidly forged into a single organization back in 2011. From that moment on, no internal distributed structures were required. Their tasks and authorities were re-assigned and concentrated to the county-level governmental commissioners and district office directors; at the same time, offices started to consist only of divisions and departments (see Table 1 below). Due to the re-definition of organizational and professional control, the management, supervisory and monitoring licences were also clearly determined.19 Compared to the original structure, the current administrative offices of the government boast a seasoned internal structure, a more centralized control scheme, and more dynamic leadership.

\subsubsection{The Second Round of External Integration}

To simplify territorial state administration, two solutions were implemented. In some cases, integration meant only the assimilation of certain specialized tasks and their related personnel, as happened with the Hungarian State Treasury, National Health Insurance Fund and Office of Immigration and Nationality. In two cases, however, integration was realized by merging complete organizations into the GOs. These were the Inspectorates for Environment, Nature and Water and the Mining Inspectorates. The 'government office corpus' established in 2011 was successful in accepting new organizations and responsibilities during 2015, and this tendency (horizontal expansion of government offices) is likely to continue in the future.

To facilitate the understanding of the core concept behind the internal organizational changes and the external integration, Table 1 has been prepared below. The table showcases the events that occurred 'under the hood' between 2010 and 2015, that is the development of the specialized agencies working as units of the mid-level public administration apparatus.

Table 1: Organizational changes in mid-level state administration with the progress of the integration process (2011-2015)20 


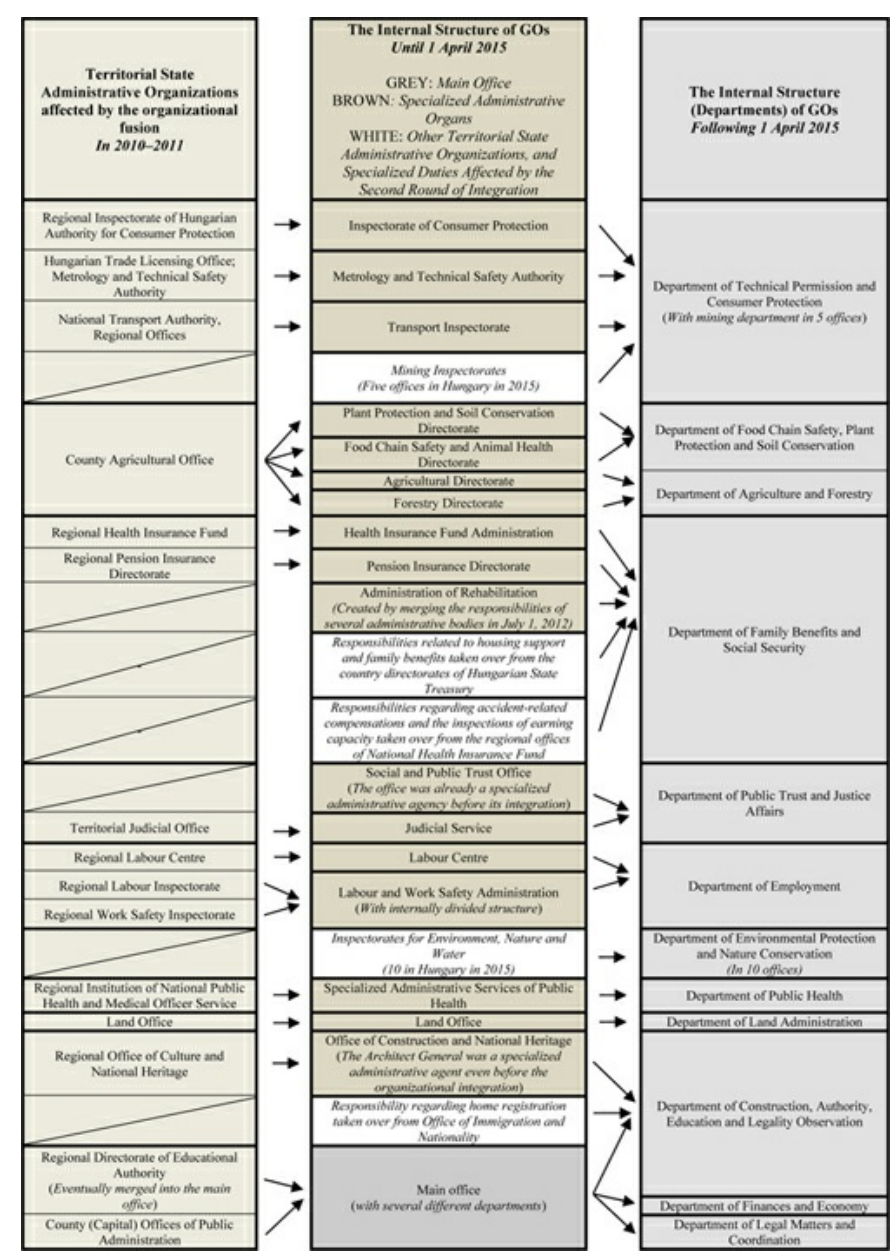

Source: Table 1 was edited by Attila Barta.

It is therefore not an overstatement that in the past years, the government interventions have been focusing on the territorial level;21 more precisely, on the mid-level government offices and the district government windows. The GOs became the nucleus of the re-defined middle level of public administration: the government aspires to use them in the unification of deconcentrated state administration (shattered back then during the Democratic Transformation). This endeavour - unparalleled even on an international level 22 - is truly a large-scale aspiration: just consider that while the 20 GOs employed roughly 20.000 civil servants in 2011, their number was increased to about 33.500 by April 2015 (it is almost $1 / 4$ of the whole civil servants in Hungary). It should therefore come as no surprise, that the scale of identified monetary support (provided from the central budget) was also increased: while in 2011 it accounted for 88.4 billion HUF, it was around 114.7 billion HUF in 2015.

As it is apparent from the above train of thought, the reformation of the county and capital government offices was far from being only a mere organizational change. I suppose it is obvious that the system is facing a new generation of government offices. This of course does not mean that there are no pending issues: for example, even by considering only the daily operation of the organization, we can pinpoint several areas of improvement. For an organization of this scale, even the system of countersigning official documents can be a daunting task to set up, not to mention the geographical challenges: in the current structure, employees working for the same department (or for the same division in case of district offices) may work on different premises, a factor resulting in numerous challenges in communication and work efficiency. For example, the Capital Government Office of Budapest operated more than 130 offices in 2015, which conveyed the suggestion of rationalizing its premises.

\subsection{A Quick Look at the Rest of the Deconcentrated Actors}


As it is apparent from the summary, the transformation of 2015 was as important as the establishment of the GOs back in 1 January 2011. However besides the notable administrative integration, the recent years have also seen a tendency of latent disintegration. Because of this latter trend, the types of deconcentrated administrative bodies in 2015 were basically equal to the amount that the system had back in 2011 (see Figure 1 below).

Figure 1: Changes in the Annual Number of Specialized Territorial Administrative Organizations (2010-2015)

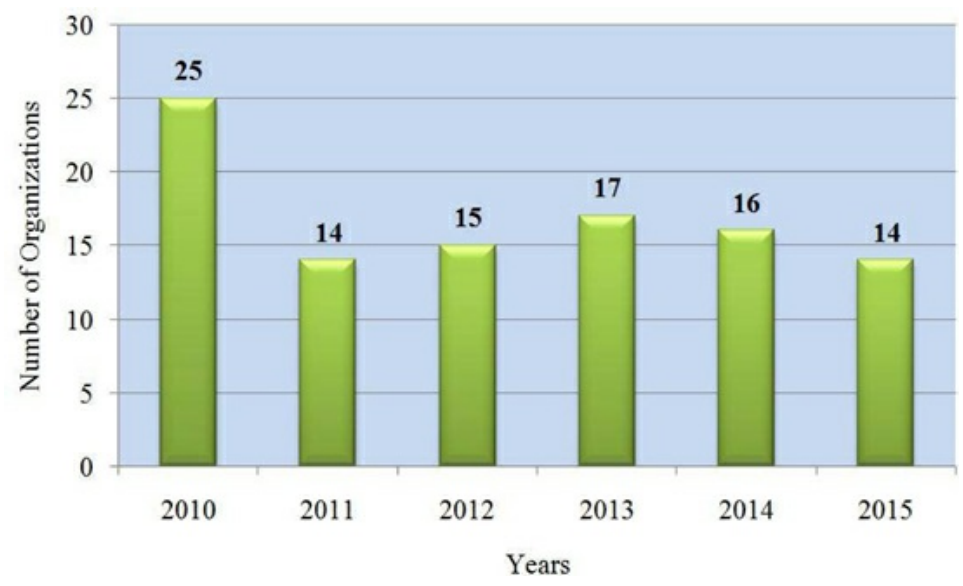

Source: Figure 1 was edited by Attila Barta

As we can see in the Figure above, in 2010 there were 25 types of deconcentrated organs with specialized tasks. Although this category received a new organization; National Land Trust with operational deconcentrated units, the same year also saw the inception of the National Media and Infocommunications Authority. With its establishment, the regional bodies of the former National Communications Authority have been removed from this category.

One year later, there were a notable decrease, then increase. The causes: the beginning of 2011 saw the merging of 14 specialized deconcentrated administrative authorities, and the unification of the former public administration offices. Therefore, the number of related organizations decreased. At the same time, the regional offices of the Hungarian Investment and Trade Agency were established. On 1 May 2011, the regional directorates of the National Institute for Quality and Organizational Development in Healthcare and Medicines and the regional offices of National Health Insurance Fund were also created as 'hidden' deconcentrated organizations.

In 2012 the number of territorial state administrative organizations increased, because the regional bodies of the National Institute for Environment were created.

In 2013 seventeen types of deconcentrated bodies functioned outside the GOs. The causes behind this number were as follows: the government absorbed several operational tasks that had formerly been delegated to local self-governments, resulting in the creation of a new system of deconcentrated institutions. New organizations included the Educational Districts of the Klebelsberg Institution Maintenance Centre and the County Directorates of Social Affairs and Child Protection.

The number of deconcentrated organs decreased in 2014, because the Hungarian Investment and Trade Agency ceased to be a body of state administration; hence its deconcentrated bodies were no longer considered parts of the public administration system.23 In 2015 this trend was continued when the Mining Inspectorates and the Inspectorates for Environment, Nature and Water were merged into the county/capital GOs.

Most of the mid-level deconcentrated bodies ( 5 types) belong to the agricultural and ( 3 types to the) human capacity portfolios (the latter mostly preoccupied with unemployment-, education-, and public health-related tasks), just as they did earlier. 24 The latter can be explained with the shift of responsibilities: starting from 2010, mid-level human capacity matters formerly handled by county-level self-governments were transformed into a state administration responsibility. At the same time, the maintenance of social, medical, and educational institutions reached such a level and specialties that neither them, nor the deconcentrated bodies of tax and treasury administration (described below) were affected by the integration with territorial government offices. 


\section{The Way Forward?}

The overview of the administrative structure resulting from the process described above is shown in the following link. The figure is about the system of state administration and local self-governments in Hungary in mid-2016. Triangles indicate offices, while circles indicate public bodies (the figure was translated and updated by Attila Barta, on the basis of István Balázs' original illustration):

http://jog.unideb.hu/documents/tanszekek/kozigazgatasi/201617 szi flv/the system of state administration and los governments in hungary in mid-2016.jpg

The following section of my essay considers some plans and tendencies that may pave the way for future improvements in the middle level of Hungarian public administration.

\subsection{Who is in Charge?}

Following 2010, the number of ministries was radically decreased. Still, in early 2017 , a new central organizational reform is planned that would affect around 50 institutions. The goal of this transformation is to achieve a simpler administrational structure by drastically decreasing the number of background institutions supporting the ministries. This will be mostly achieved by merging these institutions into the ministries themselves. The effects of this reorganization are, however, far more expansive: many of the daily tasks will be delegated to the middle level of public administration (that is, to the GOs 25 ). This readily fits the plan which calls for a Hungarian state administration which is operated solely by ministries, GOs, and DOs.

In case the above plans will be fully realized, the number of specialized deconcentrated bodies of state administration is expected to be decreased by three besides the GOs, starting from 2017 and beyond.

In correlation with the above changes, the procedural law of the authorities will also be simplified.26 Considering that the government and DOs allow the handling of increasingly more administrative cases (for example, the capital government office and its districts handled almost two million cases alone), legislation aims to concentrate the first instance licenses of authority to the middle level of public administration. In line with the above changes, second instance tasks and authorities would be assigned to ministries or (if the case was started at district offices) to capital and county GOs. To summarize, official licenses would remain in the sphere of state administration by simplifying their administrative background. At the same time, the jurisdictional system of Hungarian public administration would also transform. 27

\subsection{Fine-Tuning District Administration}

The recent years confirmed that the government considers GOs to be the 'pillars' of Hungarian public administration, and keeps expanding their competences. During the establishment of districts, the underlying goal was to keep those cases with state administrative character (originally assigned to self-governments) at the notary, which fall under local regulations and jurisdiction. At the same time, cases requiring country-level management should be transferred to district level.28 However, when jurisdiction transferred the responsibilities from the notaries to the districts, they inevitably distanced them from clients. To avoid the drastic decrease of administration locations, the government established several local DOs. Where the foundation of local branch offices was unfeasible, specialized clerks were trained and employed.

Due to the above developments, the currently existing 19729 districts will be supported by 270 government windows by the end of 2016. At the same time, the system of approximately 900 municipal specialized clerks (serving approximately 2400 municipalities) will also be kept. By mid-2016, the types of cases handled by government windows reached around 1.500, and legislation still aims to expand this list. At the same time, additional government windows are planned to be opened in department stores and train stations to ease their accessibility.

Thanks to the expansion elaborated above, district-level administration is increasingly becoming the preferred entry point for clients in handling official matters. In other words, the districts and the government windows become the most direct administrative manifestation (or 'face') of the central administration. In my opinion, the fine-tuning of the district system is inevitable; however, in light of the upcoming elections of 2018, I expect no further drastic transformation. That said, I think there is nothing to prevent the assignment of rare tasks requiring specialized knowledge to specific districts. This aspiration already has some examples: starting from 1 January 2017, the central hub of environmental protection will be the Government Office for Pest County, while the family events of Hungarian citizens residing abroad have been registered nation-wide by the Government Office of the Capital City Budapest since 2015. 


\section{3 'The Young Siblings'}

As mentioned in Section 3.2, the middle-level of state administration contained several specialized duties that were 'protected' from reorganization from the start. These included the bodies of tax and treasury management, which 'walked their own path' and evolved in parallel with the system of GOs.

The independence of the tax authority is clearly marked by the fact that its institutional structure has already been reorganized before the establishment of capital and county GOs.30 The organization (employing approximately 20.000 officials and handling one of the largest amounts of cases and clients in the public administration sector) is separated from mid-level GOs even today. That said, this organization also saw fundamental reforms in 2016. This resulted in the simplified operation of the tax authority: the number of organizational units and senior managers were halved. At the same time, plans were made to enable the management of taxation matters in GOs as well.

Another important and independent organization within the public administration structure is the State Treasury, whose profile began its transformation already in 2015 (see the related changes in Section 3.1.2). In the future, all state payments are expected to be handled by this organization; at the same time, the introduction of the so-called selfgovernment ASP (Advanced Service Provider) is also related to its further developments. The goal of this IT-system (connected to the State Treasury) is to grant users access to applications running on remote servers, allowing selfgovernments to perform document management, accounting, or taxation matters through a uniform system. 31 While several self-governments welcomed this development with lukewarm enthusiasm at best, it is still expected to be realized by 1 January 2018 .

\subsection{IT Solutions and GOs}

It is a commonly accepted observation nowadays that computerization can make public administration more effective: hence, IT-infrastructure developments quickly gained importance. Enabling the possibility to manage official matters from home is advantageous for citizens and public administration bodies alike: it can reduce the number of clients in the offices, and enables the automatization of management, along with faster communication.

When it comes to in-office solutions, I think that a key aspect in increasing the integration of the mid-level government office system should be the support of its leaders. The GOs and DOs increased both in numbers and in their scope of authorities; hence, every effort must be taken to help their leaders having a clear and up-to-date picture on the processes of the organization. Computerizing the work by setting up and maintaining Management Information Systems (MIS) is a considerable facilitator to that: by using such advanced information technology (IT) solutions, institutional decision-making can become more grounded and swift.

Similar improvements can be achieved by introducing e-Administration, that is using IT solutions for services aimed outside the offices. While the use of IT solutions is undoubtedly the way to go, and related developments were certainly more aimed and coordinated in this area, I still consider these improvements sporadic at best in the system. Therefore, I think that e-Administration should be implemented in multiple stages, along the line of the most frequently handled case types, all the while considering both the matters requiring personal appearance, and also the (generally senior) segment of the Hungarian population who prefer to handle their administrative matters by visiting the office in person. 22

\subsection{Public Servants or State Servants?}

However, despite the large-scale ideas and plans, it would be a mistake to forget about the skilled and dedicated civil servants: without them, these offices (and the entire system of public administration) would be worth nothing. Legislation also realized this, and responded by creating the legal status of 'state servants' on 1 July 2016.33 As a pilot of this change, only officials working for the DOs received this legal status at first. 34 The logic behind this development is outward expansion: the government aims to change the legal status of professionals working in state administration gradually, in multiple stages. 35 By 1 January 2017, all public servants working for the GOs would receive the new legal status; then, from 2018, the new status would be expanded to officials employed by the ministries and other central bodies of public administration. This approach would allow not just the raise of salaries, but could also be a motivational factor in the recruitment of new colleagues as well as keeping the experienced workforce.

Besides the potential advantages, the sustainability of the above process should also be considered. Can the above transformation be finished completely? And if so, then what will be the legal status of the officials employed in non-state administration areas, like self-governments? 


\section{Conclusions}

In my opinion, the large-scale transformation of the Hungarian public administration system was driven not just by the fiscal and economic crisis, but (similarly to some other European countries) $\underline{6} 6$ the need to clearly define the role of the state as well. I firmly believe that the re-centralisation efforts and the reinforcement of deconcentrated state administration within mid-level public administration were the most obvious manifestations of the effort in reinforcing state roles, and improving its integrity in public administration. The tight-scheduled series of changes elaborated above aligns with the intensive duty-based reorganization which characterizes Hungarian public administration since 2011. The latest and forthcoming changes in the GOs and their districts are a direct continuation of the reform which aims to increase the administrative capacity of the Hungarian State and Government.

While mid-level public administration is still organized on a divided structure [territorial state administration and territorial type self governments (like counties, cities with the rights of counties, and the capital city) see the link above], its state administration segment definitely became more integrated (albeit with exceptions, as noted above). This is because the government aims to handle the same (or increasing) amount of responsibilities with a reduced number of state administration organizations. The direct result of this was the establishment of such mega-organizations as the GOs, 37 the National Tax and Customs Administration, or the institution maintenance bodies. With the plan of merging central administrative bodies to ministries, the number of such organizations is expected to increase.

The status of the government offices fulfilling the territorial representation of the government has strengthened, and it clearly became the leading actor of the reorganized mid-level, thanks to the constant expansion of its sphere of authorities (by mid-2016, 5 million clients visited the GOs and DOs). In light of these developments, it is no surprise that no further reforms are planned for the system of local self-governments.

With its horizontal expansion, the GOs can facilitate a more efficient maintenance, and can reduce the costs of keeping deconcentrated state administration operational. This can be achieved, among others, by unifying procurement, maintaining a joint car fleet, or centralizing the arrangement of energy efficiency developments.

Considering that public administration is a monopoly, it is hard to decide whether an administrative reform or intervention is successful, efficient, and supportable. However, it is certainly an achievement if it increases client and societal satisfaction, and the transformation in the years behind us aimed to improve this very type of satisfaction. However, it must be taken into account that a permanent state of reforms works against consolidation, and opposes the stabilization of the administrative environment and predictable management - after all, constant changes block and upset the regular operation of public administration, even if they do so temporarily.

Personally, I think that the internal consolidation of the offices, and the concentration of the organizational and professional control on the territorial level of administration was a necessary step in 2015. However, I am also convinced that further optimal solutions inevitably require performing model experiments before imposing any further reforms. The 'grassroots' introduction of the 'state servant' legal status could be a sign of this; in any way, it is a certainty that the changes related to administrative personnel, procedures, and organizations can only be a success if they are planned in consideration with each other.

I am sure that the best course of action can only be the balanced and pragmatic development of the administrative system. Each country must choose the direction that keeps the realisation of their specific needs in view, and is defined within the limits of their own possibilities. I hold that the solutions elaborated above can really contribute to the creation of the customer-friendly public administration. After all, let us not forget that 'administratio' also meant assistance and service in Latin.

\section{References}

1 B. Guy Peters, Jon Pierre, The SAGE Handbook of Public Administration, 513 (SAGE Publications Ltd., 2012). Caroline E. Covell, Sustainable Development for Public Administration: Effective Administrative System of the 21st Century Public Administration, 9. Available at SSRN: $\underline{\text { http: } / / \text { ssrn.com/abstract }=2789785}$ or http://dx.doi.org/10.2139/ssrn.2789785 (accessed 3 June 2016).

2 Meetika Srivastava, Globalisation and Public Administration: A Study of the Term, Globalisation', Its Nature, Meaning, Characteristics and Impacton Public Administration, Available at SSRN: http://ssrn.com/abstract $=1508013$ or http://dx.doi.org/10.2139/ssrn.1508013 (accessed 1 August 2016).

3 Peters, Pierre, supra n.1, at 508. https://doi.org/10.2139/ssrn.2789785 
$\underline{4}$ Cf. G. Fodor Gábor, Stumpf István, Neoweberi állam és jókormányzás, 3 Nemzeti Érdek 5-26 (2008). Also Wolfgang Drechsler, The Reemergence of 'Weberian' Public Administration after the Fall of New Public Management, The Central and Eastern European Perspective, 6 Halduskultuur 94-108 (2005). Or from earlier, see Christopher Pollit, Geert Buckaert, Public Management Reform. A comparative Analysis, (Oxford University Press, Oxford, 2004).

5 Tiina Randma-Liiv, Riin Savi, Introduction to the Special Issue: The Impact of the Fiscal Crisis on Public Administration, 1 Administrative Culture 4 (2014).

6 See e.g. Tiina Randma-Liiv, New Public Management versus Neo-Weberian State in Central and Eastern Europe, http://iss.fsv.cuni.cz/ISS-50-version1-080227 TED1 RandmaLiiv NPMvsNWS.pdf (accessed 22 July 2014).

Z Peters, Pierre, supra n.1, at 597. https://doi.org/10.2139/ssrn.2789785

8 See Patyi András, Rixer Ádám, Hungarian Public Administration and Administrative Law, 304-320 (Schenk Verlag, Passau, 2014). And OECD (2015), Hungary: Reforming the State Territorial Administration, OECD Public Governance Reviews, OECD Publishing, Paris. http://dx.doi.org/10.1787/9789264232921-en (accessed 17 April 2016).

2 While the government had regional representative bodies between 1990 and 2010 as well, their duties and licences were different. Between 1990 and 1994, this task was fulfilled by the 'Köztársasági Megbízott' (government commissioner). Between 1994 and 2006, the assigned offices were called 'Fővárosi Közigazgatási Hivatal' and 'Megyei Közigazgatási Hivatalok' (capital public administration office and county public administration offices, respectively). Between 2006 and 2008, the body was called 'Regionális Közigazgatási Hivatal' (regional public administration office). Finally, from 2009 until September 2010, it was known as 'Regionális Államigazgatási Hivatal' (regional state administration office). Barta Attila, New Trends in The Territorial Representation of Governments, 1 Curentul Juridic 75-84 (2012).

10 See the the CXXVI ${ }^{\text {th }}$ Act of 2010 on the Capital and County Government Offices, and on the Amendments Related to the Establishment of Government Offices and the Integration of Territorial State Administration.

11 The Fundamental Law of Hungary, Article 17., Paragraph (3)

12 As defined by the Fundamental Law of Hungary and the CLXXXIX ${ }^{\text {th }}$ Act of 2011 on the Hungarian Local SelfGovernments.

13175 so-called 'járás' in the countryside, and 23 so-called 'kerület' in Budapest.

14 Kéki Zoltán: A kistérségi és a körzeti igazgatás, 233 in Csefkó Ferenc (ed.), Ünnepi kötet Ivancsics Imre egyetemi docens, decan emeritus 70. születésnapjára (Pécs, Kódex, 2008).

15 See the thematic issues of Új Magyar Közigazgatás 2012, and 2014. Also see Zöld-Nagy Viktória, Virág Rudolf, $A$ területi államigazgatás integrációja (Budapest, Nemzeti Közszolgálati és Tankönyvkiadó, 2013). Finally, see Barta Attila, Területi államigazgatás Magyarországon (Budapest, Gondolat, 2013).

16 Related to this see Barta Attila, Területi kormányhivatalok 2.0. A középszintủ államigazgatás továbbfejlesztése 2015ben, 1 Kodifikáció és Közigazgatás 39-47 (2015). http://kodifikator.hu/letoltes/category/16-2015-evi-i-szam (accessed 23 June 2015).

17 http://www.kormany.hu/download/8/42/40000/K\%C3\%B6zigazgat\%C3\%A1s feljeszt $\% \mathrm{C} 3 \% \mathrm{~A} 9$ si strat $\% \mathrm{C} 3 \% \mathrm{~A} 9 \mathrm{gi}$ 41-52, (accessed 30 June 2015).

18 For example, the reconstruction of the citizenship's trust towards public administration is a sociological question that takes at least $8-10$ years to research and restore (if not more).

19 For other interesting details on the new regulations, see the work of Papp Dorottya, http://www.arsboni.hu/hatekony kozigazgatas de milyen aron.html (accessed 26 March 2015).

20 The internal structure of some offices (such as that of the Government Office for Pest County or the Government Office of the Capital City Budapest) may differ from the ones included in the table. The reasons of this can be numerous: on the one hand, responsibilities may vary in the different counties; and on the other hand, it can occur that certain departments and divisions are numbered due to limitations in the number of personnel. The table is aimed to serve as an illustration only, and thus indicates just general solutions. 
21 Balázs István, A közigazgatás változásairól Magyarországon és Európában a rendszerváltástól napjainkig, 190-193 (Debreceni Egyetemi Kiadó, Debrecen, 2011).

22 Szamel Katalin, Balázs István, Gajduschek György \& Koi Gyula, Az Európai Unió tagállamainak közigazgatása (Budapest, Complex, 2011). The government visibly aims to share the 'Hungarian way' on an international level. See the early 2015 symposium on the recent results and the future direction of the reforms on territorial public administration below: http://radioorient.hu/adasok/2015-01-15 nemzetkoziszimpozium (accessed 10 June 2015).

23 Since the regional directorates of the National Institute for Quality and Organizational Development in Healthcare and Medicines and the regional offices of National Health Insurance Fund rarely based the topics of a thorough analysis, the number of these organizations may be indicated differently in the related professional materials.

24 See Ferrel Heady, Public Administration, A comparative perspective, 182 (Taylor \& Francis Group, 2001).

25 The specific steps and the schedule of the reorganization are detailed in Government Decree 1312/2016. (VI. 13.) on the Measures Related to the Revision of Central Offices and Ministry Background Institutions Operating as Publicly Financed Institutions.

26 See the $\mathrm{CXL}^{\text {th }}$ Act of 2004 on the General Regulations of Public Administrative Procedure on Authorities and the Government Decree 1352/2015. (VI. 2) on the Various Tasks Related to the Preparations for the Act on Public Administration Civil Procedure and the Act on General Administrative Procedure.

27 http://www.kormany.hu/download/c/c8/50000/20150514\%20Jelent\%C3\%A9s\%20az\%20\%C3\%A1ltal\%C3\%A1n (accessed 5 September 2016).

28 Patyi, Rixer, supra n.1, at 318.

29 In the meantime, a district has been merged into another.

30 See CXXII ${ }^{\text {th }}$ Act of 2010 on the National Tax and Customs Administration.

31 For details, see Government Decree 257/2016. (VIII. 31.) on the ASP System of Self-Governments.

32 See Veszprémi Bernadett, Az információs társadalom kihivásai és a közigazgatás reakciói (Debreceni Egyetemi Kiadó, Debrecen, 2015).

33 The polarization of public administration personnel already started when the e 'mployees of the tax authority received their own career benefits.

34 See LII ${ }^{\text {th }}$ Act of 2016 on State Servants.

35 Currently, clerks employed in the public administration sector are uniformly called 'public servants', while officials working in state administration are known as 'government officials'. Since 1 July 2016, the 'state servant' legal status basically exists within the latter group.

36 http://www.eastr-asso.org/content/eastr-0 (accessed 5 September 2016).

37 In mid-2016, 33.702 public servants work at the 20 GOs. 